Contacts

Publisher: Ben Crowe

Editor: Paul Smaglik

Marketing Manager: David Bowen

European Head Office

London

The Macmillan Building

4 Crinan Street

London N1 9XW, UK

Tel +44 (0) 2078434961

Fax +44 (0) 2078434996

e-mail: naturejobs@nature.con

Naturejobs Sales Director

Nevin Bayoumi (4978)

UK/ RoW/ Ireland:

Matt Powell (4953)

Andy Douglas (4975)

Frank Phelan (4944)

Scandinavia/ Spain/ Portugal

Evelina Rubio Håkansson (4973)

Natureevents: Sille Opstrup (4994)

France/ Switzerland:

Amelie Pequignot (4974)

Production Manager: Billie Franklin

To send materials use London

address above.

Tel +44 (0) 2078434814

Fax +44 (0) 2078434996

e-mail: naturejobs@nature.com

Naturejobs web development:

Tom Hancock

Naturejobs online production

Stefan Hales

European Satellite Office

Germany/ Austria/ Italy/

The Netherlands/ Belgium

Patrick Phelan, Odo Wulffen

$\mathrm{Tel}+498954905711 /-2$

$\mathrm{Fax}+498954905720$

e-mail: p.phelan@nature.com o.wulffen@nature.com

US Head Office, New York

345 Park Avenue South

10th Floor, New York, NY 10010-1707

Tel +1 8009897718

Fax +18009897103

e-mail: naturejobs@natureny.com

US Sales Manager: Peter Bless

Japan Head Office, Tokyo

MG Ichigaya Building (5F),

19-1 Haraikatamachi,

Shinjuku-ku,

Tokyo 162-0841

Tel +81332678751

Fax +81332678746

Asia-Pacific Sales Director:

Rinoko Asami

e-mail: rasami@naturejpn.com

\title{
naturejobs
}

\section{Mental barriers}

A t Stanford University in Palo Alto, California, the Clark Center, the hub of the university's Bio-X multidisciplinary programme, sits just a stone's throw from the medical school, the computer science building, the chemistry department and the engineering department. Does that naturally encourage interaction? Not necessarily, said Charles Kruger, emeritus dean of research and graduate policy, speaking to a delegation from the Biotechnology Industry Organization's annual meeting in San Francisco last week.

"Walking back and forth is no problem," Kruger told the visitors. "The problem is thinking you can do that." Kruger's words resonate at a time when 'interdisciplinary' is a buzzword, but making it really happen is more difficult. The Clark Center, with its central circular courtyard, corridors on the outside, glass-walled labs, and a coffee shop on the top floor, is engineered to create interactions.

Bricks, mortar and style are being used as a tool to recruit people (Nature 424, 858-859; 2003) and facilitate interaction and inspiration (Nature 424, 718-720; 2003). But mindset may be more important than architecture. "How do you get promoted if you are one of many authors on a paper?" asked one audience member. "Who gets credit for a patent when a large team is involved in the discovery" asked another.

Kruger's reply was that people who opt to work in an interdisciplinary environment self-select for cooperation and tend to sort out such issues with a little thought. "The physical barriers here are not as great as the mental barriers," he said. The real issue may be finding such common ground - and career advancement rewards - for scientists who don't work in such environments.

\section{Paul Smaglik}

Naturejobs editor
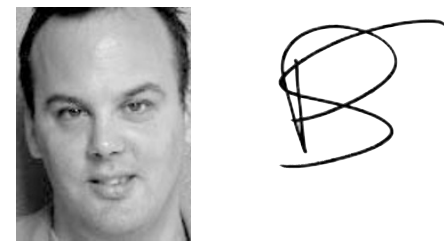

\section{Contents}

\section{POSTDOCS \& STUDENTS}

High-flying postdocs

p786

\section{CAREER VIEW}

\section{Scientists \& Societies}

When your spouse gets a job

Graduate Journal

Thrifty solutions

Movers

Ruedi Aebersold

\section{WWW.NATUREJOBS.COM}

Career centre

Information on the scientific job market

FOCUS

SPOTLIGHT

RECRUITMENT

ANNOUNCEMENTS

EVENTS 